\title{
An Enigmatic Funnel Find of the Somogyvár-Vinkovci Culture from Balatonőszöd-Temetői dủlö in Transdanubia, Hungary
}

\author{
Tünde Horváth ${ }^{\mathrm{a}^{*}}$, Katalin Gherdán ${ }^{\mathrm{b}}$, Gabriella Kulcsár ${ }^{\mathrm{a}}$, György Sipos ${ }^{\mathrm{c}}$, Mária Tóth ${ }^{\mathrm{d}}$ \\ anstitute of Archaeology Research Centre for the Humanities, Hungarian Academy of Sciences, H-1014 Budapest, Úri u. 49. Hungary \\ ${ }^{b}$ Faculty of Humanities, Institute of Archaeological Sciences, H-1088 Budapest, Múzeum krt. 4/B. Hungary \\ ${ }^{c}$ University of Szeged, Department of Physical Geography and Geoinformatics, H-6722, Szeged, Egyetem u. 2-6. Hungary \\ ${ }^{d}$ Institute of Geological and Geochemical Research, Research Centre for Astronomy and Earth Sciences, Hungarian Academy of Sciences, H-1112, \\ Budapest, Budaörsi út 45. Hungary
}

\section{ARTICLE INFO}

\section{Article history:}

Received: 29. November 2012

Accepted: 20. June 2013

\section{Keywords:}

Early Bronze Age

Transdanubia

ceramic funnel

Somogyvár-Vinkovci culture

\begin{abstract}
$A B S T R A C T$
A small section of an Early Bronze Age settlement made up of pits was uncovered at the prehistoric, multi-period site of Balatonőszöd-Temetői dülö. In addition to ceramics of the Somogyvár-Vinkovci culture, the finds from Pit 2563 included an enigmatic artefact of baked clay. Despite the fact that analogous archaeological finds and various archaeometric analyses have provided several clues for a conclusive determination of its function, comparable finds nonetheless suggest that it might in all probability be associated with dairying or metalworking.
\end{abstract}

\section{Introduction}

In addition to the finds and features of other cultures and periods, a section of an Early Bronze settlement was also uncovered at Balatonőszöd-Temetöi dülő (Site M7/S-10) during the excavations preceding the construction of the M7 Motorway in 2001-2002 (Figure 1).

Features of the Early Bronze Age Somogyvár-Vinkovci and of the late Somogyvár-Vinkovci/proto-Kisapostag horizon were scattered over a 100,000 $\mathrm{m}^{2}$ large area (twenty-seven pits, five of which yielded late SomogyvárVinkovci/proto-Kisapostag finds, of which the pottery totalled 1037 pieces). ${ }^{1}$ In order to compare the Late Copper Age and Early Bronze periods regarding the archaeological typology of the finds, their chronology and the pottery making techniques, six samples taken from Early Bronze Age ceramics were submitted for petrographic and other archaeometric examinations (thin section microscopy

\section{${ }^{*}$ Corresponding author. E-mail: horvath.tunde@btk.mta.hu}

${ }^{1}$ The final report containing a detailed description of the site and its finds is in progress. and X-ray diffraction; Gherdán, Horváth, Tóth 2012) to complement the Late Copper Age data (Gherdán, Horváth 2009; Gherdán et al. 2010; Horváth 2010). A sample for radiocarbon measurement was collected from one Early Bronze Age feature, while TL/OSL dating was performed on a Late Copper and an Early Bronze Age artefact (Horváth et al. 2010; Horváth 2011a).

The present study focuses on the date, the archaeometric analysis and the possible function of an unusual artefact, a clay funnel recovered from Pit 2563b.

\section{Archaeological interpretation of the clay funnel}

\subsection{The clay funnel}

Feature 2563 uncovered in Trench 34/7 was a deep beehive shaped pit (Pit 2563b) which yielded $3 \mathrm{~kg}$ of ceramics. A small intrusion or layer (2563a) was noted in its upper section, from which we recovered a perforated mussel ornament. ${ }^{2}$

${ }^{2}$ Similar perforated ornaments, although made from different mussel species (lacustrine Unio species) which were perforated in a different manner and a different spot, were also recovered from the features of the Middle 


\section{Early Bronze Age}

\section{Somogyvár-Vinkovci}

Somogyvár-Vinkovci/ Proto-Kisapostag

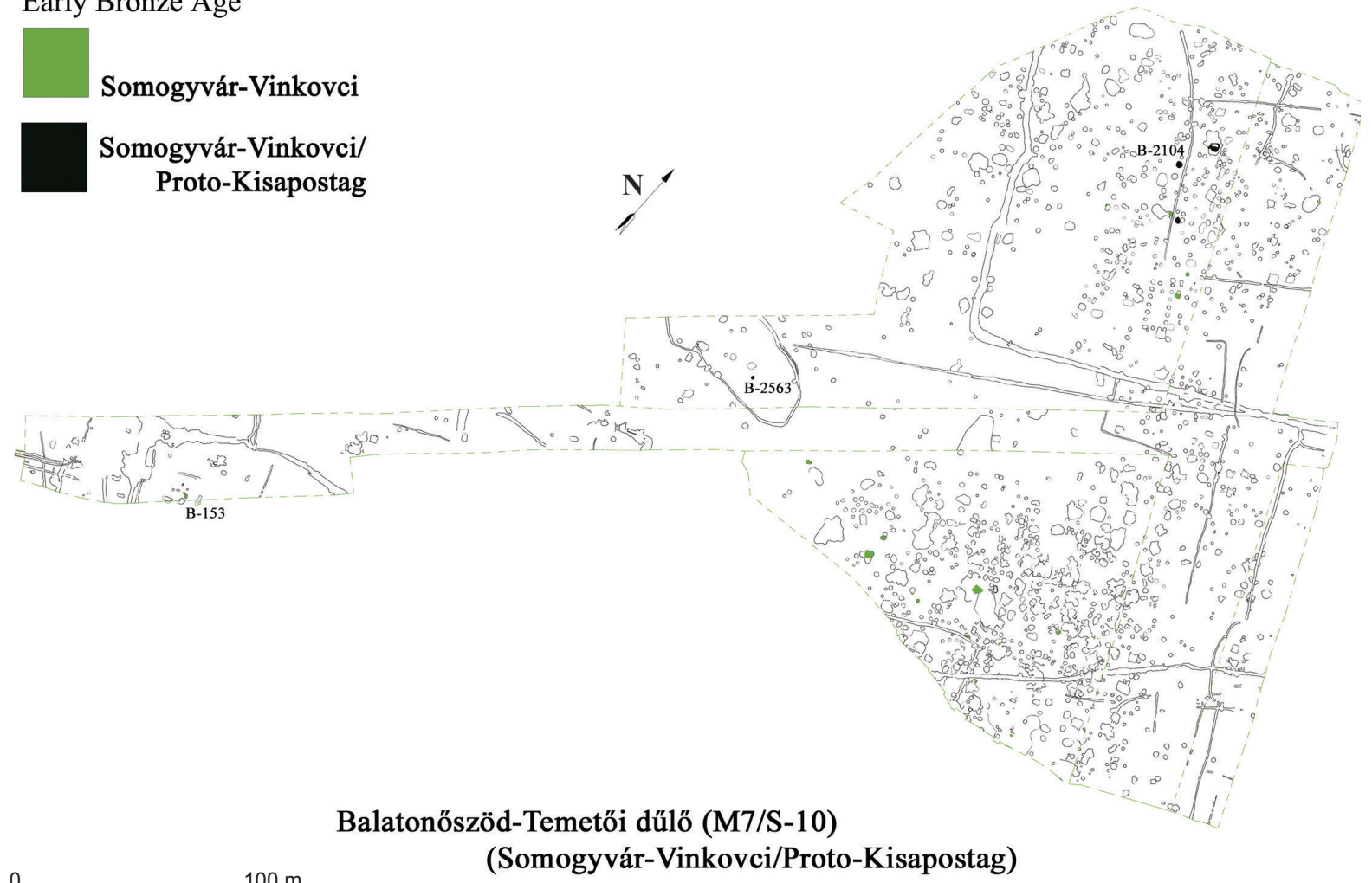

(Somogyvár-Vinkovci/Proto-Kisapostag)

0 $100 \mathrm{~m}$

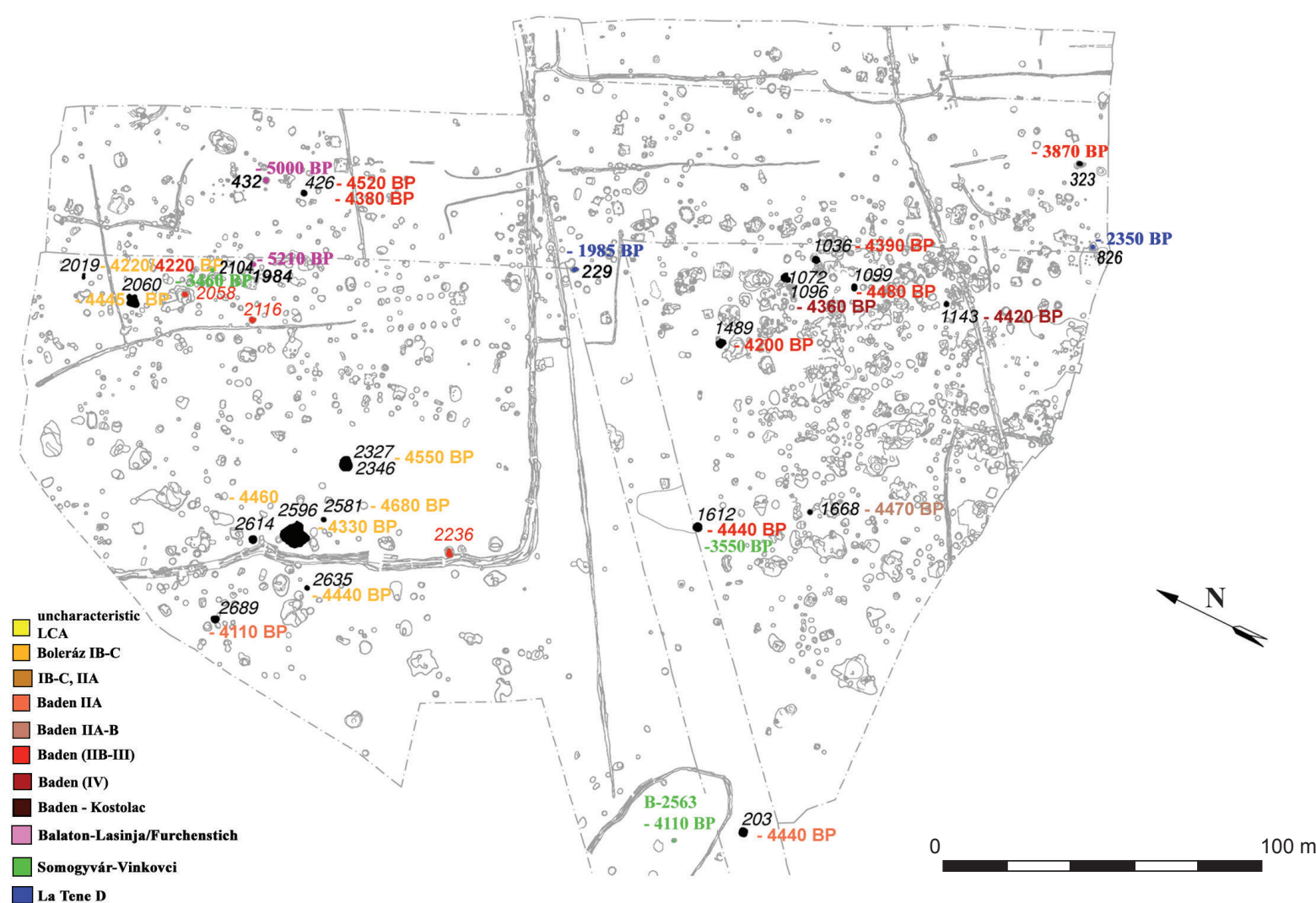

Balatonőszöd-Temetői dűlő: dated features

Figure 1. Balatonőszöd-Temetői dủlő: 1 - Settlement features of the Early Bronze Age settlement; 2 - radiocarbon and TL/OSL dated Middle and Late Copper Age, Early Bronze Age and Late Iron Age settlement features. 

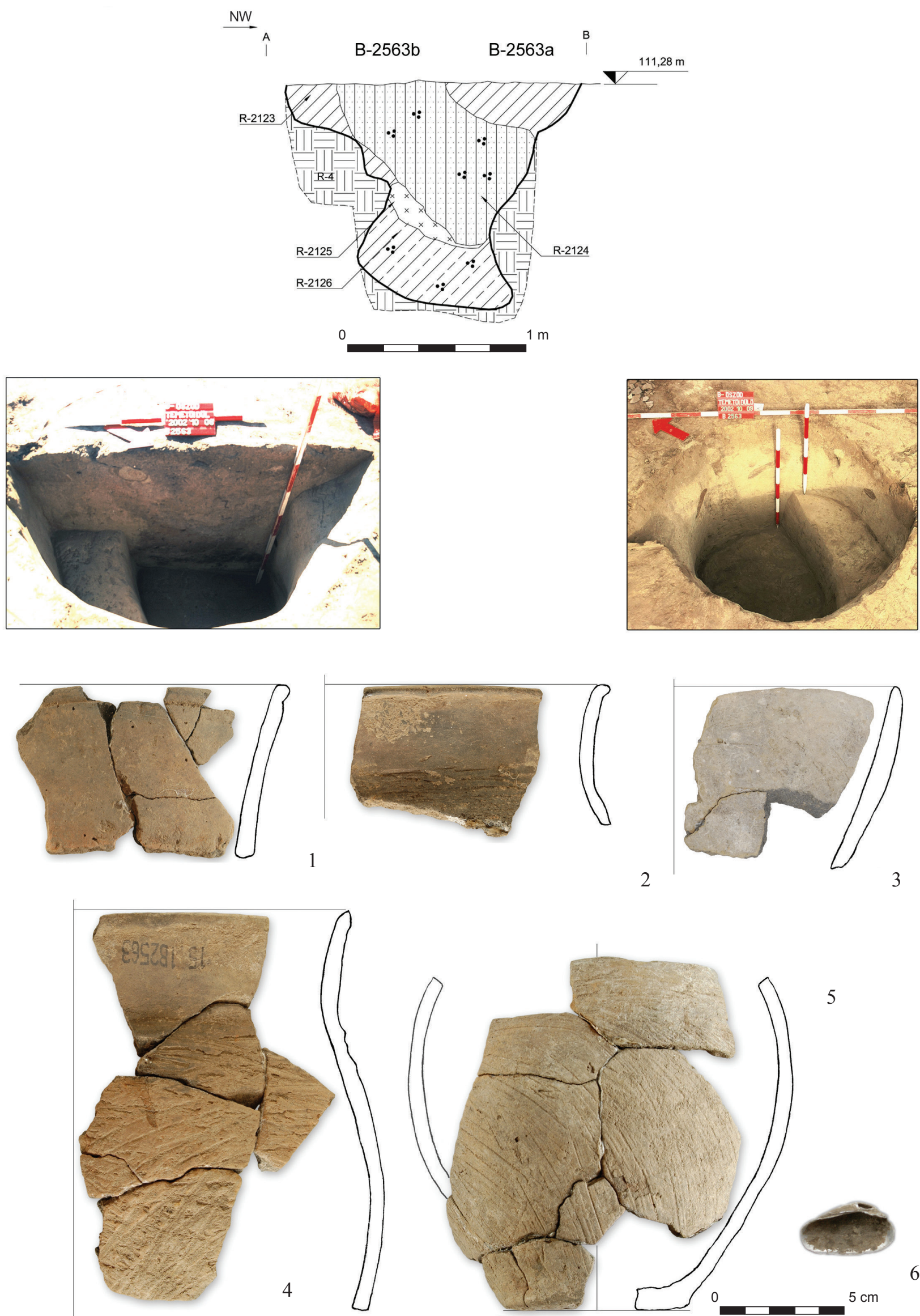

2

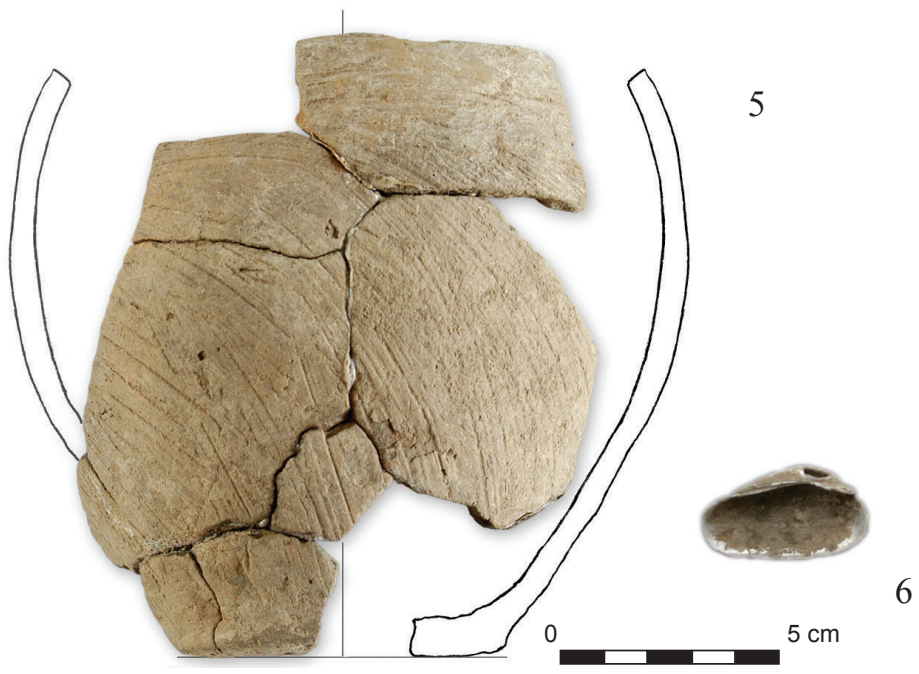

Figure 2. Balatonőszöd-Temetői dúlő - Pit 2563 and its finds. 

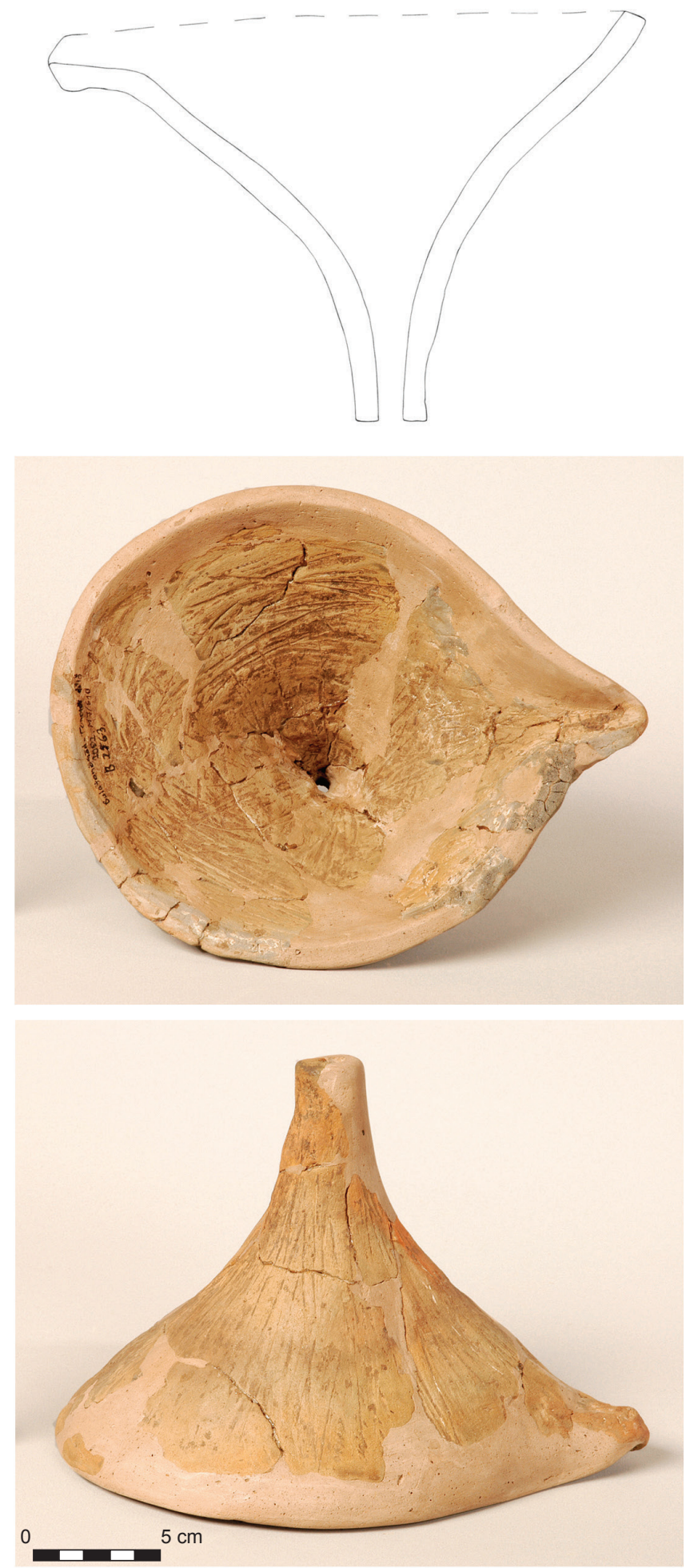

Figure 3. Balatonőszöd-Temetői dülő - Clay funnel from Pit $2563 b$ (Drawing by Magda Füredi).

The Early Bronze Age pottery fragments from the pit can be assigned to the late Somogyvár-Vinkovci culture (Figure 2).

Description of the clay funnel (Figure 3): A yellowishgreyish-red funnel with an everted rim and spout. The interior is irregularly scored and bears patches of a white calcareous coating. The exterior is covered with vertical scoring. The stem of the funnel narrows gradually. Slight damage to the funnel could be noted on the rim and the base of the stem. Vitrification indicating secondary burning could be noted on the rim. The interior contained patches of a whitish calcareous coating which mostly survived in the deep scoring. Analogous finds suggest use as a milk strainer, a crucible or perhaps a tuyère. Diam. of rim, $228 \mathrm{~mm}$, diam. of stem $28 \mathrm{~mm}, \mathrm{H} .150 \mathrm{~mm}$. The TL/OSL analysis provided a date of $4110 \pm 580 \mathrm{BP} / 2110 \pm 580 \mathrm{BC}$ (Table 3).

\subsection{Formal and temporal analogies to the clay funnel}

Similar funnel shaped clay artefacts of a different form and function dating from the $3^{\text {rd }}$ millennium and the early $2^{\text {nd }}$ millennium BC are known from Lower Austria, the southern Russian steppe and the Balkans.

A funnel shaped, baked clay artefact from Unter-Mamau (today Untermamau, p. B. Sankt Pölten, Lower Austria) is housed in the collection of the Naturhistorisches Museum in Vienna (inv. no. 85.897; Figure 4.1-2). Together with various other finds, the artefact came to light in 1929, during an excavation conducted by $\mathrm{H}$. Wichmann. The funnel has a diameter of $14.2 \mathrm{~cm}$ at the top, $4.5 \mathrm{~cm}$ at the base and a height of $12 \mathrm{~cm}$. The dark brownish-grey funnel has a smooth, perhaps polished exterior and interior, and was fired in a reducing atmosphere. During the revision of the museum's holdings, the artefact was assigned to the Early Bronze Age, but without a closer cultural attribution (the finds were re-inventoried by Fritz Eckart Barth on June 25, 1984). The funnel from Untermamau was displayed among the finds shown as part of the exhibition "Der geschmiedete Himmel" in the Landesmuseum for Vorgeschichte in Halle in 2004-2005, whose centrepiece was the Nebra disc. The funnel was described as an Early Bronze Age artefact used in metalworking. ${ }^{3}$

The burials under the kurgans of the Catacomb culture excavated on the Kalmyk steppe, dated to the mid- $3^{\text {rd }}$ millennium BC, yielded several artefacts including a funnel, a milk cup and a nursing vessel which could be linked to the production and consumption of dairy products (Figure 4.3; Shishlina 2001, 24-26, Figure 5). The funnel is spouted and in this respect bears more of a resemblance to the piece from Balatonőszöd than the Lower Austrian one. Funnels without

Copper Age Balaton-Lasinja/Furchenstich culture. We therefore tentatively dated Pit 2563a to this occupation horizon. A similar perforated mussel was found among the grave goods of a Baden burial uncovered at Szigetszentmárton (Kalicz 1976, 190; Hungarian National Museum, inv. no. MNM-RÖ 72.19.9; Lichter 2010, Cat. no. 279). It is equally possible, however, that the mussel dates from the Early Bronze Age Somogyvár-Vinkovci culture and was used in metalworking. Similar mussels were deposited in steppean metalsmith burials, although their exact role in metalworking is unclear (cp. Bátora 2002, Fig. 8. 10: Kalinovka, Poltava culture, Azerbaijan; Kaiser 2005, Abb. 4. 20: Gromovka, Kurgan 1, Grave 7, Kazakhstan). The mussel from Pit 2563a was perforated through the umbo (Figure 2.6). This mussel species is alien to this region as it represents a species thriving in flowing water (Unio crassus Retzius) which does not occur in Lake Balaton at present. It could only have reached the Balatonőszöd site through trade. At present, this species thrives in larger rivers such as the Danube. We would like to thank Sándor Gulyás for the species determination.

${ }^{3}$ The funnel does not appear in the catalogue that accompanied the exhibition (cp. Meller 2004). 

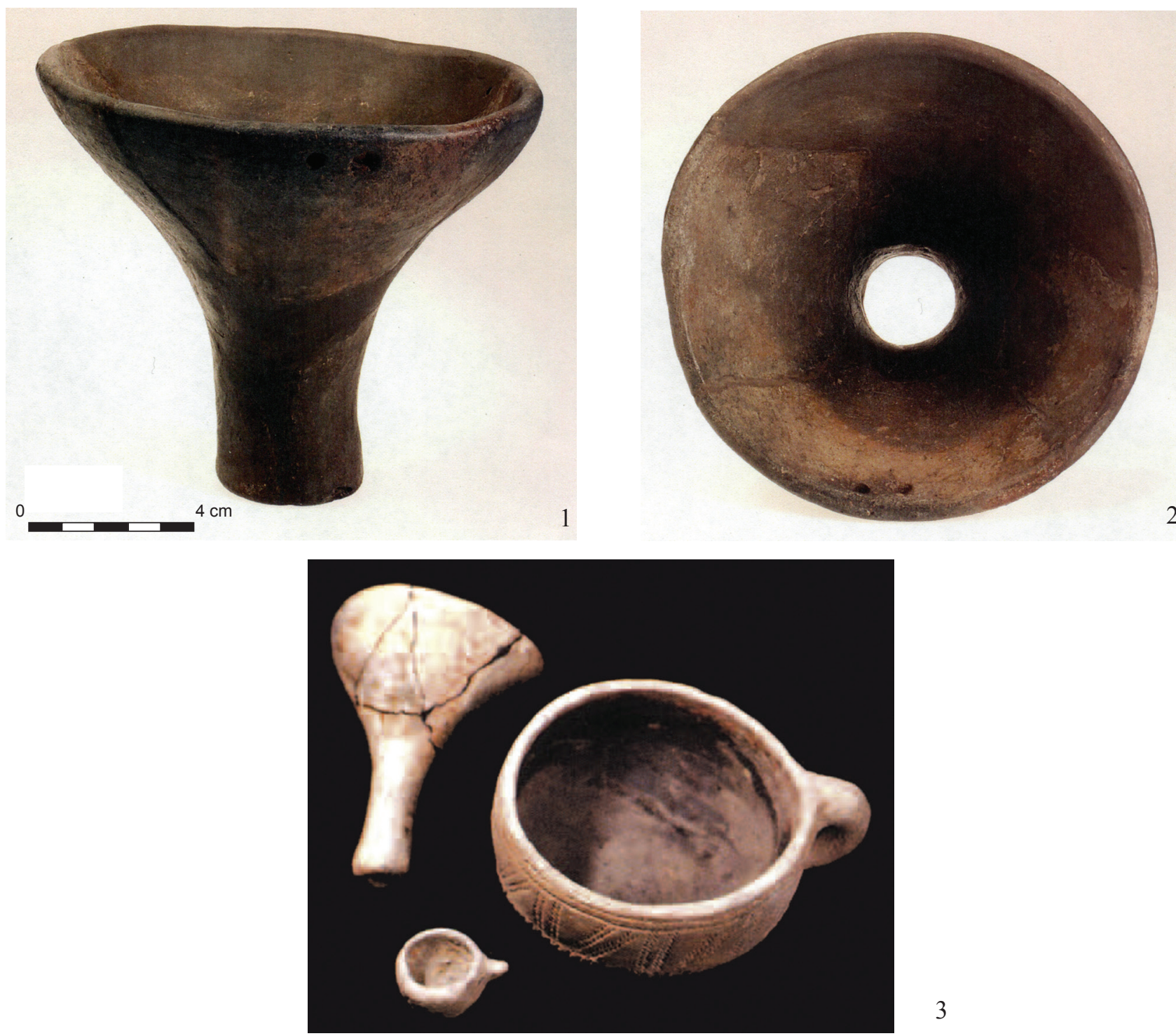

Figure 4. Clay funnels from the $3^{\text {rd }}$ and $2^{\text {nd }}$ millennium BC: 1, 2 - Unter-Mamau (Lower Austria; Naturhistorisches Museum, Vienna); 3 - various artefacts associated with dairying from Catacomb graves, Kalmykia, mid-3 $3^{\text {rd }}$ millennium BC (after Shishlina 2001, 24-26, Figure 5).

a spout are also known, such as the specimens from Kurgan 3 of Kurgan Field 1 at Mandzhikin, dated to between 2600 and 1900 BC (Shishlina et al. 1999, Figure 8, Figure 12.1).

Other sites of the Catacomb culture on the southern Russia steppe yielded an assortment of comparable finds such as an unspouted fragment with perforations under the rim from Kurgan I at Bykovo near Volgograd in the Lower Volga region (Häusler 1974, Table 11. 17), a decorated, spouted funnel from Kurgan 1 at Solenoe near Rostov in the Lower Don region (Häusler 1974, Table 24.18) and an undecorated, unspouted piece from Mamontov (Häusler 1974, Table 17.15). Similar pieces appear among the finds of the earlier and partly contemporaneous Yamnaya/Pit Grave culture as well, for example, the plain, unspouted piece from Kurgan 2 at Spornyj in the Manych Valley (Häusler 1974, Table 28.18).

A burial mound with a rich inventory of finds was uncovered in 2001 at Gruda Boljevića in the eastern Adriatic region in Montenegro. Various finds arranged in two groups were found lying above the grave-pit of the principal grave, a poorly preserved crouched burial enclosed by a semi-circle of stones. The radiocarbon measurements provided a date of 3090-3044 BC for the burial (Baković, Govedarica 2009; Govedarica 2010). A carefully polished shaft-hole axe of green granite whose shaft-hole was lined with gold foil, a trapezoidal, perforated pendant of red porphyry, ${ }^{4}$ a copper/

${ }^{4}$ Interestingly enough, the possible provenance of the lithic raw materials from which the stone artefacts imitating precious metal and luxury articles were made are not discussed in the study (i.e. whether the lithics were locally available or imports). The cultural contacts of the lavish tumulus burials of the eastern Adriatic point towards Italy, Transylvania (Poiana Ampoiţa) and the Russian steppe. If the lithic raw materials were identified correctly, deposits of green granite and vulcanites (porphyry) are known in several locations in the Balkans, as well as in the Transylvanian Range and the Carpathians. Rhyolite (granite?) deposits have been reported from the Apennine Mountains, while red dacite deposits occur in Eastern Europe, e.g. in the Caucasus. 

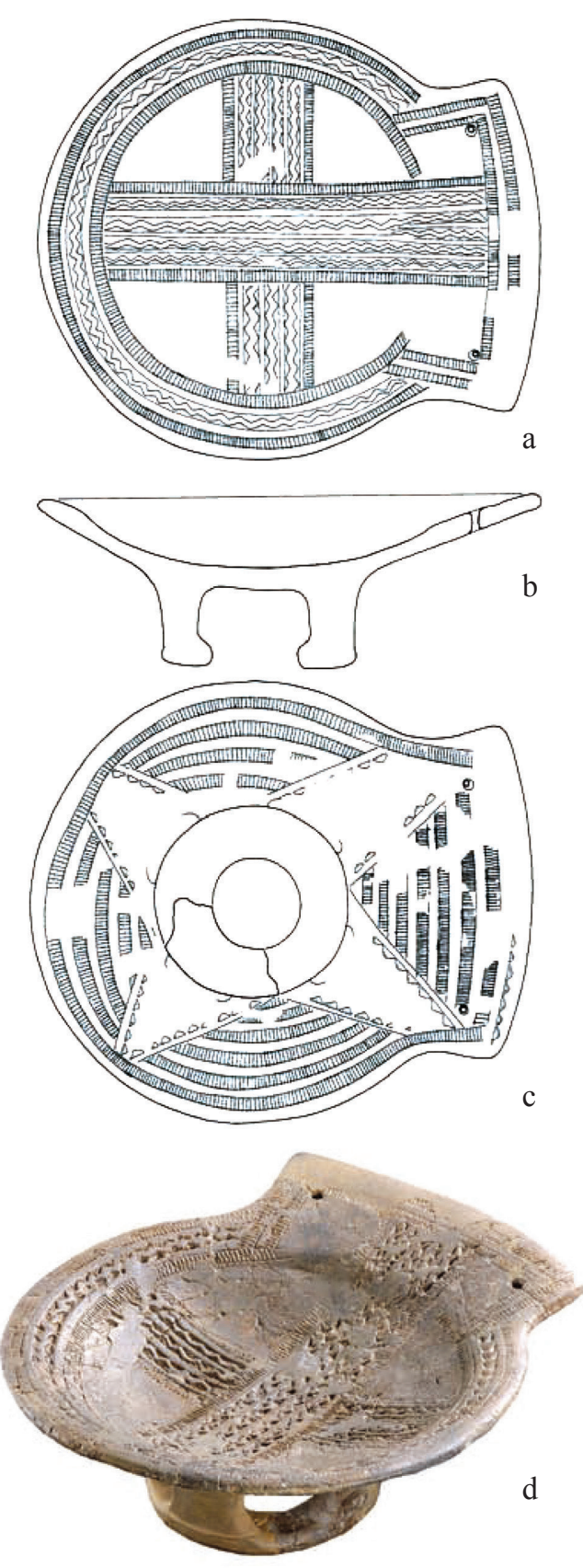

1)
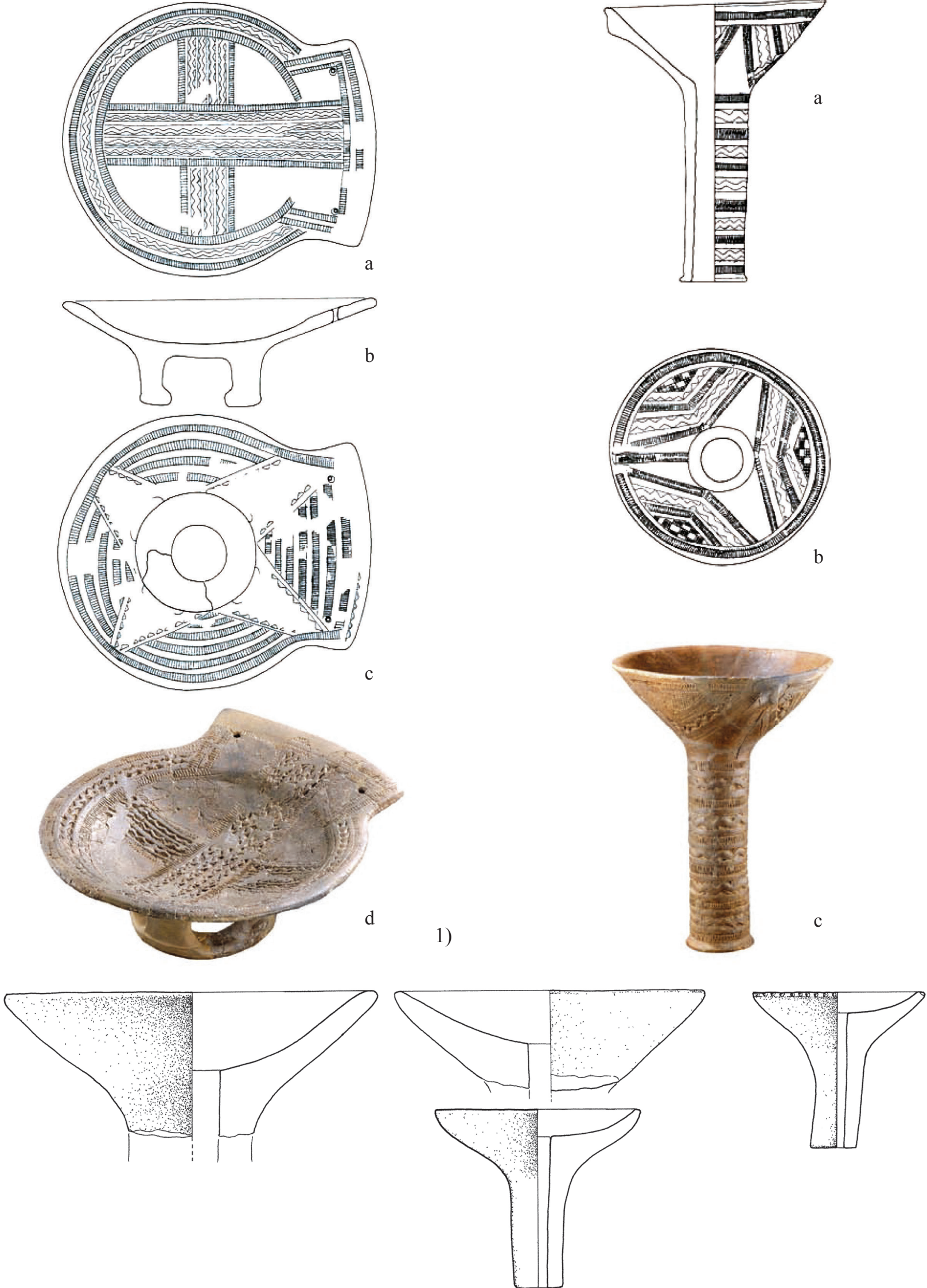
bronze dagger with a triangular blade, two golden lockrings ${ }^{5}$ and a clay lump bearing a circular imprint were found $80 \mathrm{~cm}$ above the burial. Another group of artefacts lay in the middle of the mound, at a depth of $60 \mathrm{~cm}$ from its top: an interior decorated bowl with a fenestrated pedestal (perhaps an altar or an incense burner), a lugged funnel with a decorated exterior and plain interior and a broken, decorated, one-handled jug (Figure 5.1). The unusual and currently unparalleled funnel was fired to a greyish-orange colour. It is $18.2 \mathrm{~cm}$ in height and has a diameter of $14.1 \mathrm{~cm}$ on top and $4.2 \mathrm{~cm}$ at the base. The diameter of the stem matches the size of the round imprint on the clay lump, suggesting that the latter had functioned as a stopper. The observations carried out during the excavation indicate that the assemblage had been deposited after the burial ceremony, during the construction of the burial mound. It would appear that the burial ceremony was followed by a libation and a fumigation ceremony (burnt offering), performed at the spot of the burial (Baković, Govedarica 2009, 11, 15-16, Figure 10). The burial and its finds can be assigned to the Mala and Velika Gruda type burials of Montenegro, and the southern Adriatic distribution of the Ljubljana culture.

Comparable funnels, both undecorated and adorned with a simple pattern, are known from the settlements of the Kostolac/Vučedol period (Sarvaš: Balen 2005, 49, Cat. nos 187-193, Pl. 50. 187-190, Pl. 51. 191-193; Vučedol: Vulić, Grbić 1938, Pl. 1. 2, 8; Schmidt 1945, Table 43. 1-3: two pieces from the burial chamber; Figure 5.3). These funnels were interpreted as tuyères attached to leather bellows or artefacts for pouring liquids. Their sizes differ: the pieces from Sarvaš are 11-12.8 cm high, while the ones from Vučedol include smaller specimens with a height of 4.3 to $9.8 \mathrm{~cm}$.

\section{An archaeometric analysis of the Balatonőszöd funnel and other Early Bronze Age finds}

\subsection{Petrography (Table 1)}

The six ceramic samples from the settlement's Early Bronze Age occupation can be divided into three groups: the three sherds (Samples 61-63) had a serial fabric and the nonplastic inclusions did not include diagnostic mineral and/ or rock grains for identifying the provenance (for a detailed discussion of the analyses and their results, see Gherdán et al. 2012). The raw material appears to have been alluvial sediment used without any prior preparation since no traces of tempering agents were observed.

The second group was represented by two sherds (Samples 64-65) from vessels made with a carbonate sand tempering agent. The two sherds have a hiatal fabric. The coarse (up to 1.5-2 mm large), well-rounded, rounded, occasionally subrounded carbonate rock fragments suggest a carbonate sand tempering agent. Similar tempers were identified during the petrographic examination of other Bronze Age ceramics as

\footnotetext{
${ }^{5}$ The metal articles have not been subjected to archaeometric analyses.
}

well (Kreiter 2006; Gherdán 2009). The funnel from Pit $2563 \mathrm{~b}$ can be assigned to this group.

The composition of one sherd (Sample 60) corresponds to the composition of the ceramics in Group 1 of the Late Copper Age Boleráz/Baden ceramics (Gherdán et al. 2010). The sherds are tempered with grog containing micritic carbonate rock fragments.

\subsection{X-ray powder diffraction analysis (Table 1)}

The main components identified in the ceramic samples were quartz, plagioclase, orthoclase and $10 \AA$ phyllosilicates. Chlorite, kaolinite, calcite and dolomite are subordinate, the residue of components which disintegrated during firing. Among the main components, the proportion of plagioclase and orthoclase is reversed in certain samples, although a systematic change cannot be demonstrated. In samples 60-65, chlorite and kaolinite are the typical clay mineral residues, while the other grains are calcite $>$ quartz $>10 \AA$ phyllosilicate (sericite-illiite) $>$ dolomite, plagioclase, corresponding to the presence of limestone. The (001) and (002) reflections of chlorite can be more or less demonstrated depending on the firing temperature. Traces of amphibolite were identified in several samples. The carbonate grains trapped in the vessel body did not disintegrate owing to relatively low firing temperatures and rapid heating. The firing temperature was determined from the residual phases (calcite, dolomite), the increased reflection of the transformed phases (chlorite [001] and [002]) and the presence of kaolinite, based on the academic literature on the thermic transformation of calcareous clays and the data obtained earlier from the Late Copper Age samples of the Balatonőszöd site (Gherdán et al. 2010). The firing temperature of the ceramics was generally around $600-650^{\circ} \mathrm{C}$ (and $650-700^{\circ} \mathrm{C}$ in one case), i.e. much lower than in the Late Copper Age (Gherdán et al. 2012).

\subsection{Archaeology}

Apart from several general formal similarities between the Late Copper Age Baden and the Early Bronze Age Somogyvár-Vinkovci ceramic styles (such as the presence of variants of flasks and vessels with asymmetric handles among the Baden finds, both vessel types of which are known from the Early Bronze Age contexts as well), there is no connection whatsoever between the two ceramic traditions either regarding pottery production techniques, or in terms of vessel typology (see Horváth 2011a for a detailed discussion). The overwhelming majority of the Early Bronze Age vessels were tempered with carbonate sand or, more rarely, calcareous sand, although natural, untreated clay was also used in pottery production. The vessels are more compact than the ceramics of the Middle and Late Copper Age and appear to be more carefully fired. However, the $\mathrm{X}$-ray diffraction analyses indicated that they were fired at lower temperatures than the Copper Age ceramics which were fired at $850-900^{\circ} \mathrm{C}$.

The coarsening and scoring techniques in Late Copper Age pottery also differ radically from the Early Bronze Age 
Table 1. Archaeometric analysis of the Early Bronze Age ceramics of the Somogyvár-Vinkovci/proto-Kisapostag period from Balatonőszöd-Temetői dülő (petrography by K. Gherdán, X-ray powder diffraction by M. Tóth, archaeological description by T. Horváth).

Table 1 presents the data (the fabric and the composition of the non-plastic inclusions) from the detailed petrographic examination of the Early Bronze Age ceramics.

Specified fabric data: colour of the groundmass in plain (IN) and crossed polarised light $(+\mathrm{N})$, isotropy of the groundmass (categorised according to a three point scale as weak, moderate or strong), fabric type (serial with a continuous grain size distribution or hiatal with a grain size distribution with more than one maximum), sorting of the non-plastic inclusions (good, moderate or poor). If the grain size distribution has more than one maximum (in the case of hiatal fabrics), the ranges for the maxima are also specified together with the composition of the non-plastic inclusions in each range. The grain size distribution is shown in a schematic graph, with the horizontal axis representing absolute grain size and the vertical axis representing relative quantity. The orientation of the non-plastic inclusions is also specified, if detectable. We also specify if any layers could be distinguished in the cross-section.

The proportion of the non-plastic inclusions was estimated with comparison charts. We used the following categories, based on the recommendations of the PCRG (1997): $\mathrm{R}=$ rare $(<3 \%), \mathrm{S}=$ sparse $(3-9 \%), \mathrm{M}=$ moderate $(10-19 \%), \mathrm{C}=$ common $(20-29 \%), \mathrm{V}=$ very common $(30-39 \%), \mathrm{A}=\mathrm{abundant}(>40 \%)$.

\section{Sample no.}

Archaeological description

Petrographic group: Group 1

\section{6}

Layer No. 925. Somogyvár-Vinkovci or Árpádian Age? Indistinct, medium thick-walled body sherd, probably from an amphora. Reddish-brown exterior, coarsely smoothed: the imprints of vertical organic matter can be noted (from textile or vegetal matter). Brick red interior, smoothed. Tempered with white limestone. Household pottery.

\begin{tabular}{|c|c|c|c|c|c|}
\hline \multirow[t]{2}{*}{ Colour of groundmass } & \multicolumn{2}{|c|}{$1 \mathrm{~N}$} & \multicolumn{3}{|l|}{ Brown } \\
\hline & \multicolumn{2}{|c|}{$+\mathbf{N}$} & \multicolumn{3}{|l|}{ Dark brown } \\
\hline \multicolumn{3}{|l|}{ Isotropy of groundmass } & \multicolumn{3}{|l|}{ Strong } \\
\hline \multicolumn{3}{|l|}{ Fabric } & \multicolumn{3}{|l|}{ Hiatal } \\
\hline \multicolumn{3}{|c|}{ Amount of non-plastic inclusions (\%) } & \multicolumn{3}{|l|}{$15-20 \%$} \\
\hline \multicolumn{3}{|c|}{ Sorting } & \multicolumn{3}{|l|}{ Poor } \\
\hline \multicolumn{3}{|l|}{ Grain size distribution: } & \multicolumn{3}{|c|}{$\begin{array}{l}\text { Two maxima: } 50-250 \mu \mathrm{m} \text { (mineral fragments, carbonate rock fragments); } \\
500-1500 \mu \mathrm{m} \text { (carbonate rock fragments, grog) } \\
\text { Maximum grain size: } 3700 \mu \mathrm{m} \text { (carbonate rock fragment, grog) }\end{array}$} \\
\hline \multicolumn{3}{|l|}{ Orientation } & \multicolumn{3}{|c|}{ Weak } \\
\hline \multirow[t]{6}{*}{ Outer layer } & colour & $1 \mathrm{~N}$ & \multicolumn{3}{|l|}{ Dark brown } \\
\hline & & $+\mathrm{N}$ & \multicolumn{3}{|l|}{ Black } \\
\hline & isotrop & & \multicolumn{3}{|l|}{ Strong } \\
\hline & average & ickness & \multicolumn{3}{|l|}{$200-250 \mu \mathrm{m}$} \\
\hline & bounda & & \multicolumn{3}{|l|}{ Sharp } \\
\hline & compos & & \multicolumn{3}{|l|}{ Similar to groundmass } \\
\hline \multirow[t]{8}{*}{ Non-plastic inclusions } & minera & rains & monocrystalline quartz & C low sphericity, angular & $50-300 \mu \mathrm{m}$ \\
\hline & & & polycrystalline quartz & S low sphericity, subrounded & $300-500 \mu \mathrm{m}$ \\
\hline & & & feldspars & $\mathrm{R}$ & \\
\hline & & & muscovite & $\mathrm{R}$ & \\
\hline & & & accessories & $\mathrm{R}$ & \\
\hline & rock fra & nents & carbonate rock fragments & $\begin{array}{l}\text { C low sphericity, well rounded; } \\
\text { high sphericity, well rounded }\end{array}$ & $200-3700 \mu \mathrm{m}$ \\
\hline & other & & grog & $\mathrm{M}$ & $500-3700 \mu \mathrm{m}$ \\
\hline & & & fossil fragment & $\mathrm{R}$ calcareous fossil fragment & $1800 \mu \mathrm{m}$ \\
\hline
\end{tabular}

\section{Sample no.}

Archaeological description

Petrographic group:

\section{6}

Pit 2563 (Somogyvár-Vinkovci-proto-Kisapostag). Spouted funnel (restored). Yellowish-greyish-red, with straight, everted rim. The stem of the funnel narrows downward. The interior is irregularly scored and covered with a white, calcareous coating. The exterior covered with vertical scoring. Possible function: milk strainer/ crucible/tuyère (?). Diam. of rim 228 mm, H. $150 \mathrm{~mm}$

$\mathrm{TL} / \mathrm{OSL}$ date: $4110 \pm 580 \mathrm{BP}, 2110 \pm 580 \mathrm{BC}$ 
Table 1. Archaeometric analysis of the Early Bronze Age ceramics of the Somogyvár-Vinkovci/proto-Kisapostag period from Balatonőszöd-Temetői dülő (petrography by K. Gherdán, X-ray powder diffraction by M. Tóth, archaeological description by T. Horváth). (Continuation).

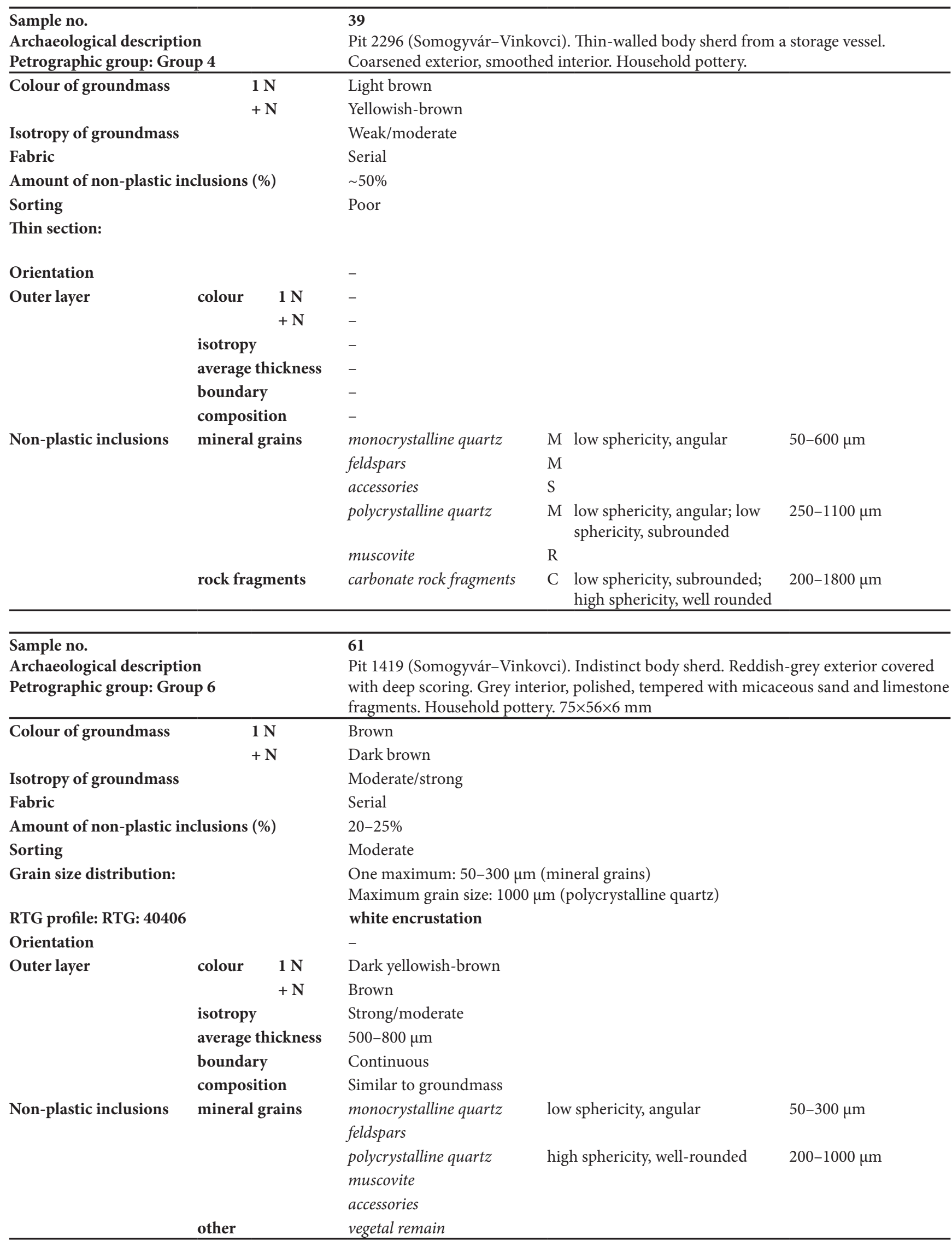


Table 1. Archaeometric analysis of the Early Bronze Age ceramics of the Somogyvár-Vinkovci/proto-Kisapostag period from Balatonőszöd-Temetői dülő (petrography by K. Gherdán, X-ray powder diffraction by M. Tóth, archaeological description by T. Horváth). (Continuation).

\section{Sample no.}

Archaeological description

Petrographic group: Group 6

\section{2}

Pit 2104 (Somogyvár-Vinkovci-proto-Kisapostag). Indistinct body fragment. Brownish-grey exterior covered with deep scoring. Grey interior, tempered with micaceous sand and limestone fragments, broken where the clay slabs were fitted together. Household pottery. $79 \times 52 \times 6 \mathrm{~mm}$

TL/OSL date: $4070 \pm 570 \mathrm{BP}, 2070 \pm 570 \mathrm{BC}$

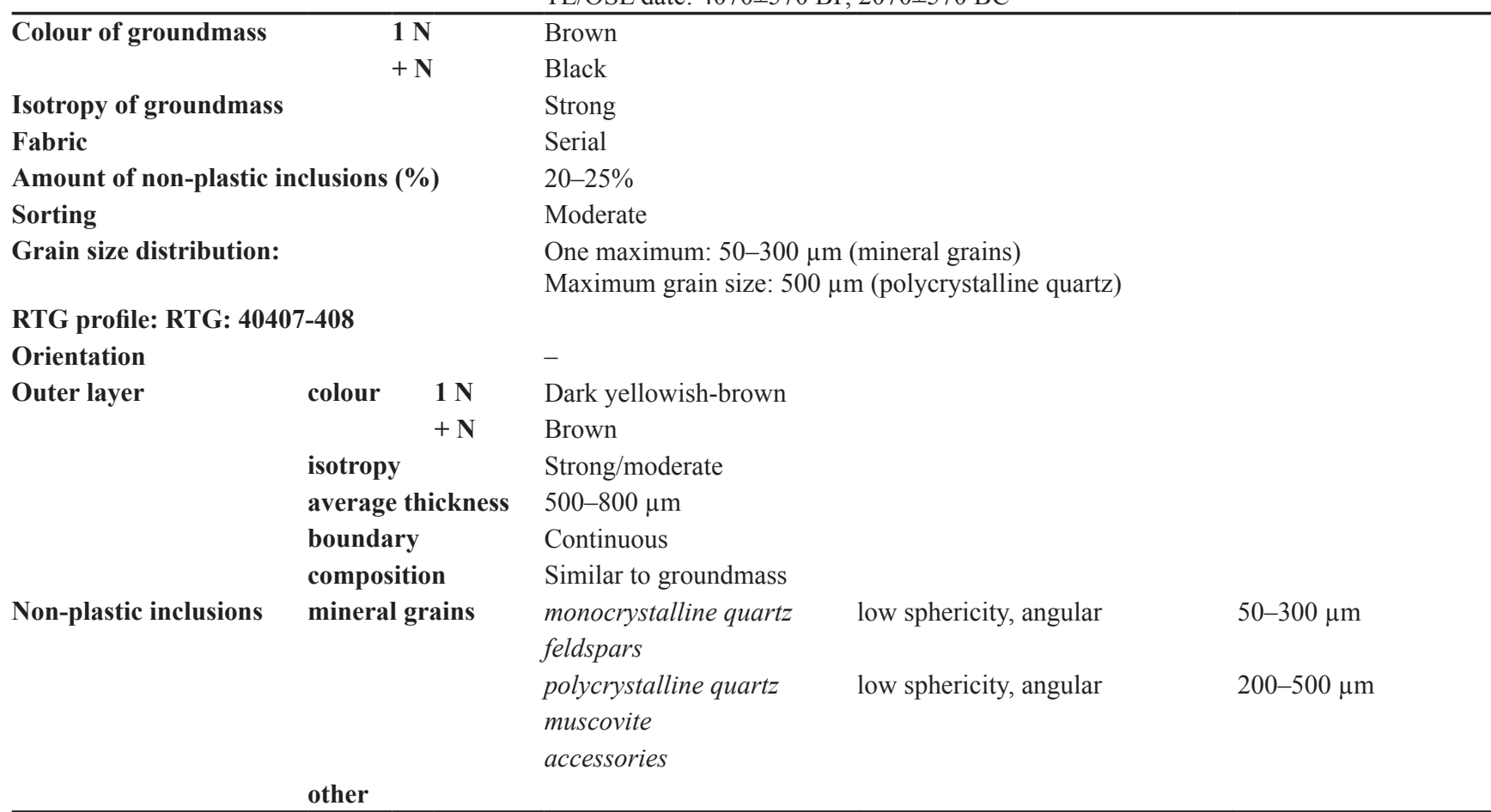

Sample no. 63

Archaeological description

Petrographic group: Group: 6

Colour of groundmass
Isotropy of groundmass
Fabric
Amount of non-plastic in
Sorting
Grain size distribution
RTG profile: RTG: 40409
Orientation
Outer layer

\section{3}

colour $\quad 1 \mathrm{~N}$
isotropy
average thickness
boundary
composition
mineral grains

Pit 2104 (Somogyvár-Vinkovci-proto-Kisapostag). Basal body fragment. Grey, polished exterior and interior, covered with a thin whitish encrustation (limescale?) on the exterior and interior. Tempered with micaceous sand. Fine ware. $78 \times 67 \times 4 \mathrm{~mm}$

\section{Brown \\ Black}

Strong

Serial

$20-25 \%$

Moderate

One maximum: 50-300 $\mu \mathrm{m}$ (mineral grains)

Maximum grain size: $500 \mu \mathrm{m}$ (monocrystalline quartz)

Brown

Dark brown

Strong/moderate

200-500 $\mu \mathrm{m}$

Continuous

Similar to groundmass

monocrystalline quartz low sphericity, angular $\quad 50-500 \mu \mathrm{m}$ feldspars

polycrystalline quartz low sphericity, angular $\quad 200-300 \mu \mathrm{m}$

muscovite

accessories

other 
Table 1. Archaeometric analysis of the Early Bronze Age ceramics of the Somogyvár-Vinkovci/proto-Kisapostag period from Balatonőszöd-Temetői dülő (petrography by K. Gherdán, X-ray powder diffraction by M. Tóth, archaeological description by T. Horváth). (Continuation).

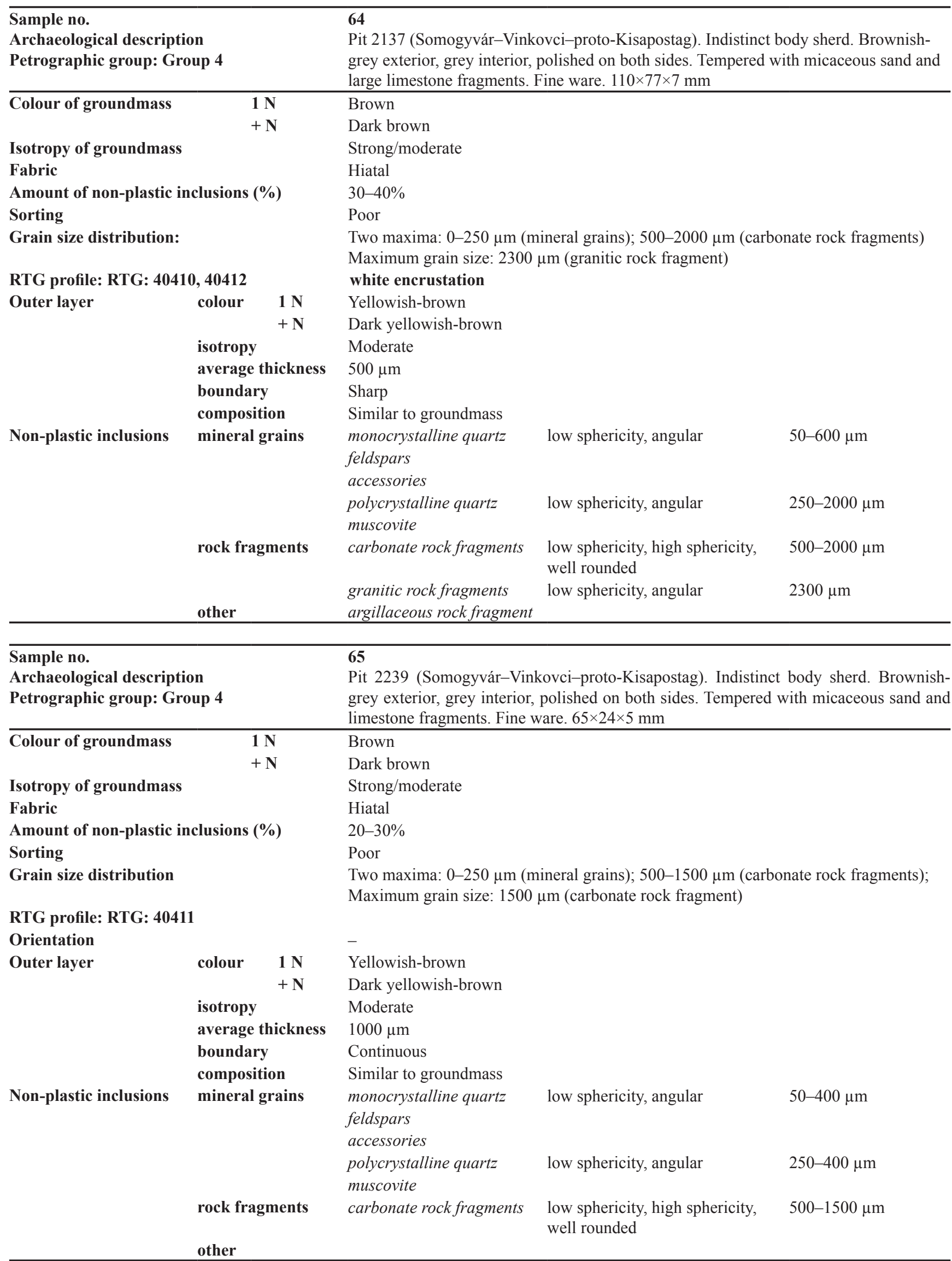


practice: the scoring is deeper and was carried out using a thinner vegetal matter (perhaps with brooms or twigs), while the coarse coating is identical with the vessel fabric and was only applied to the vessel exterior (on the Boleráz and Baden vessels, the coarse coating forms an entirely separate layer which can be clearly made out in the vessel's cross-section). The potting techniques also differed: the potters of the Early Bronze Age created their vessels by joining flat slabs of clay and consequently shaping them into the desired form. The same technique was used for repairing vessels.

None of the excavated Early Bronze Age settlement features and finds can be associated with pottery production or metalworking, nor did we observe organic residues or pitting from contact with acids on the ceramics which may have been caused by dairy products.

We decided to submit the funnel, whose function remains enigmatic, to additional archaeometric analyses to determine whether it had any unique features or traits distinguishing it from the other ceramic finds.

In addition to determining its firing temperature and raw material, the primary goal of the clay funnel's archaeometric analysis was to identify possible clues for determining its function and use. Its form suggested that it was used for pouring dilute liquids while the firing temperature also supported this interpretation (Table 2). The estimated firing temperature, based on the observed mineralogical phases, excludes its direct use in metalworking. Although it seems possible that the different discolorations on the funnel's surface could be associated with its one-time use, the examination of the discoloured patches (Samples 38216, 38285, 38839. with diverse structures) did not yield satisfactory results in this respect: apart from calcite and gypsum (the latter was used in the vessel's restoration), no other clearly identifiable phases were above the detection limit threshold.

The funnel was made from clay tempered with limestone and was fired at a low temperature. The structure and phases of the rapid heating and short firing duration can be identified. The X-ray powder diffractograms are typical for the amorphous phase (an increased background due to the short range order), although this diffuse reflexion does not originate from the glass phase, but from the untransformed remains of the decomposed clay minerals losing their structural water. None of the examined samples reached a $800^{\circ} \mathrm{C}$ firing temperature. The joint presence of calcite and dolomite is conspicuous, indicating the use of limestone as a tempering agent. As dolomite does not crystallise owing to subsequent soaking, its presence is consequently additional proof for a low firing temperature and short firing. We analysed samples not only from the funnel's surface and from the inner fracture surface of the separated parts, but also part of the samples for the TL/OSL analysis.

These results tally with the measurements for the samples taken from other sections. The maghemite contents of the inner parts also indicate a short firing in a reducing atmosphere without a diffusion controlled transformation. The phases resemble the ones observed in samples from Late Copper Age vessels of the Balatonőszöd site (Gherdán et al. 2010), reflecting the local origin of the clay used for pottery production during the Middle and Late Copper Age, and the Early Bronze Age. In addition, the funnel was fired at a higher temperature than the average Early Bronze Age vessel intended for daily use, despite the fact that the clay

Table 2. Balatonőszöd-Temetői dülö - The phase composition and firing temperature of the clay funnel from Pit $2563 b$.

\begin{tabular}{|c|c|c|c|}
\hline Sample & Sample no & Phase composition & $\begin{array}{c}\text { Firing temperature } \\
\mathbf{T}\left(\mathbf{C}^{0}\right)\end{array}$ \\
\hline Small red fragment from the rim & 38213 & $\begin{array}{l}\text { Quartz }>>\text { plagioclase }>\text { K-feldspar }>10 \AA \text { - phyllosilicate } \\
(\text { sericite-illite) }>\text { haematite }>\text { maghemite }\end{array}$ & $<700-800$ \\
\hline $\begin{array}{l}\text { White calcareous coating from the } \\
\text { interior }\end{array}$ & 38216 & Calcite $>$ gypsum, quartz, plagioclase & - \\
\hline Grey fragment from the rim (slag) & 38285 & Quartz $>>$ K-feldspar $>$ plagioclase $>$ dolomite $>$ calcite & $<700-800$ \\
\hline Red outer surface & 38494 & $\begin{array}{l}\text { Quartz }>\text { plagioclase }>\text { orthoclase }>10 \AA \text { - phyllosilicate (illit) }> \\
\text { maghemite }>\text { haematite (trace) }>\text { amphibolite }\end{array}$ & $<700-800$ \\
\hline Light "pinkish" & 38839 & $\begin{array}{l}\text { Quartz }>>\text { plagioclase }>\text { K-feldspar }>10 \AA \text { - phyllosilicate } \\
\text { (sericite-muscovite) }>\text { maghemite }>\text { dolomite }>\text { calcite }\end{array}$ & $<700-800$ \\
\hline Dark red pottery & 38840 & $\begin{array}{l}\text { Quartz }>\text { K-feldspar }>\text { plagioclase }>10 \AA \text {-phyllosilicate (sericite- } \\
\text { muscovite) }>\text { haematite }>\text { maghemite }>\text { dolomite (trace), calcite } \\
\text { (trace) }\end{array}$ & $<700-800$ \\
\hline Red pottery from the exterior & 38841 & $\begin{array}{l}\text { Quartz }>>\text { plagioclase }>10 \text { å-phyllosilicate (illite) }>\text { K-feldspar }> \\
\text { calcite, dolomite }>\text { maghemite }\end{array}$ & $<700-800$ \\
\hline 552 TL bore & 38842 & $\begin{array}{l}\text { Quartz }>>\text { plagioclase }>10 \text { - } \text {-phyllosilicate (illite) }>\text { K-feldspar }> \\
\text { calcite, dolomite }>\text { maghemit }\end{array}$ & $<700-800$ \\
\hline 553 TL bore & 38843 & $\begin{array}{l}\text { Quartz >> plagioclase }>10 a \text {-phyllosilicate (illite) }>\text { K-feldspar }> \\
\text { calcite, dolomite }\end{array}$ & $<700-800$ \\
\hline 554 TL bore & 38844 & $\begin{array}{l}\text { Quartz }>>\text { plagioclase }>10 \AA \text { - phyllosilicate (illite) } \\
>\text { K-feldspar }>\text { calcite, dolomite, chlorite }(001) \text {, chlorite } \\
(002)\end{array}$ & $<600-700$ \\
\hline
\end{tabular}


Table 3. Balatonőszöd-Temetői dủlő - The TL/OSL dates for the clay funnel from Pit 2563b.

\begin{tabular}{|c|c|c|c|c|c|c|c|c|c|}
\hline Sample & Lab. code & $\mathbf{W}$ & $\begin{array}{c}\mathrm{U} \\
(\mathrm{ppm})\end{array}$ & $\begin{array}{c}\text { Th } \\
(\mathbf{p p m})\end{array}$ & K (\%) & $\begin{array}{c}D^{\prime} \gamma \\
(\mathbf{G y} / \mathbf{k a})\end{array}$ & $\begin{array}{c}\text { D' } \\
\text { (Gy/ka) }\end{array}$ & $\begin{array}{c}D_{\mathrm{e}} \\
(\mathrm{Gy})\end{array}$ & $\begin{array}{l}\text { Age } \\
\text { (ka) }\end{array}$ \\
\hline $\begin{array}{l}\text { Pit } 2563 \\
\text { (funnel rim) }\end{array}$ & OSZ-552 & 0.04 & $1.97 \pm 0.40$ & $20.56 \pm 5.33$ & $1.63 \pm 0.20$ & $0.91 \pm 0.05$ & $4.60 \pm 0.47$ & $20.11 \pm 0.61$ & $4.38 \pm 0.47$ \\
\hline $\begin{array}{l}\text { Pit-2563 } \\
\text { (funnel shaft) }\end{array}$ & OSZ-553 & 0.04 & $1.97 \pm 0.40$ & $20.56 \pm 5.33$ & $1.63 \pm 0.20$ & $0.91 \pm 0.05$ & $4.60 \pm 0.47$ & $20.70 \pm 0.34$ & $4.51 \pm 0.47$ \\
\hline Pit-2104 & OSZ-554 & 0.04 & $1.80 \pm 0.36$ & $18.89 \pm 4.90$ & $1.71 \pm 0.21$ & $0.91 \pm 0.05$ & $4.36 \pm 0.47$ & $19.75 \pm 0.57$ & $4.43 \pm 0.46$ \\
\hline
\end{tabular}

$\mathrm{W}$ : as found water content

U, Th, K: radioactive element content of pottery samples, determined by a PE NexION 300D type ICP MS.

D' $\gamma$ : External gamma dose rate, measured on site by Canberra Inspector 1000 type portable NaI detector.

D': total dose rate including internal alpha and beta and external gamma dose rates.

$\mathrm{D}_{\mathrm{e}}$ : equivalent dose determined by TL applying the multiple aliquot additive method.

Age: with reference to the date of measurements - 2011 .

composition and the temper were identical. This would suggest that the funnel had been exposed to a certain amount of secondary heat effect during its use. This temperature was not as high as would be generally needed for metalworking (over $1,000^{\circ} \mathrm{C}$, for example, in the case of crucibles which came into direct contact with molten metal), but higher than what an artefact would be exposed to during a spontaneous fire such as the burning of a house or another building (Gherghiu 2003).

\section{The dating of the funnel and the Early Bronze Age features}

Radiocarbon dates were obtained for two Middle Copper Age, twenty Late Copper Age, one Early Bronze Age and two Late Iron Age features of the Balatonöszöd site. The measurements were performed in three laboratories (Debrecen, Vienna and Kiev; see Horváth 2009; 2011a; 2011b).

The currently available twenty samples for the Late Copper Age Boleráz and Baden periods indicate a date between $4680 \pm 45$ and $3870 \pm 50$ BP. The latest Late Copper Age date is $3870 \pm 50 \mathrm{BP}$, obtained for a sample taken from Pit 323, whose finds could be typologically assigned to the Baden III period. The radiocarbon date for Pit 1612, whose finds similarly represented the Baden III period, was
$3550 \pm 50 \mathrm{BP} / 2024-1750(95.4 \%)$ cal BC, a surprisingly late date calling for additional analyses (Table 4).

The Early Bronze Age occupation at Balatonőszöd can be dated to $3460 \pm 60 \mathrm{BP} / 1928-1626(95.4 \%)$ cal BC on the basis of samples taken from Pit 2104 containing ceramics in the late Somogyvár-Vinkovci/proto-Kisapostag style (Table 4). TL/OSL measurements were performed on two artefacts from Pits 2104 and 2563b representing the late SomogyvárVinkovci/proto-Kisapostag period. The dates obtained from these measurements were $4110 \pm 580 \mathrm{BP} / 2110 \pm 580 \mathrm{BC}$ and $4070 \pm 570 \mathrm{BP} / 2070 \pm 570 \mathrm{BC}$ (Table 3 ). Their mean is slightly earlier than the radiocarbon dates for the Early Bronze Age.

The dates thus caused certain confusion regarding the relative and absolute chronology of the settlement section whose occupation was dated to the late SomogyvárVinkovci/proto-Kisapostag period on the basis of the ceramic styles. Typologically, the finds can be assigned to the Early Bronze Age 2-3 phases, while the absolute chronological dates suggest a much later date around the close of the Early Bronze Age or even the Middle Bronze Age 1-2.

This would suggest that there was an at least 300 year long hiatus in the site's occupation between the Late Copper Age and the Early Bronze Age 2-3. This is also supported by the observations on the site's layout, the pottery manufacturing techniques and the typology of the ceramic finds. If the radiocarbon measurements provide, however, an accurate date for Pit 1612, a sacrificial pit of the Baden culture, this

Table 4. Balatonőszöd-Temetői dülő - Radiocarbon dates for Pits 323, 1612 and 2104.

\begin{tabular}{|c|c|c|c|c|c|c|}
\hline Sample no. & Feature & $\begin{array}{l}\text { Sample } \\
\text { type }\end{array}$ & $\begin{array}{c}\text { Deb } \delta^{13} \mathrm{C}(\mathrm{PDB}) \pm 0.2[\% \text { ] } \\
\mathrm{KI} \delta^{13} \mathrm{C}(\mathrm{PDB}) \pm 0.3[\% \circ]\end{array}$ & $\begin{array}{l}\text { Archaeological } \\
\text { period }\end{array}$ & $\begin{array}{c}\text { Conventional } \\
\text { radiocarbon age } \\
\text { BP }\end{array}$ & $\begin{array}{c}\text { Calibrated } \\
\text { radiocarbon age } \\
\text { cal } \mathrm{BC}\end{array}$ \\
\hline KI-16687 & Pit 323 & $\begin{array}{l}\text { Animal } \\
\text { bone }\end{array}$ & -19.5 & Baden III & $3870 \pm 50$ & $\begin{array}{l}2458-2291(68.2 \%) \\
2472-2202(95.4 \%)\end{array}$ \\
\hline Deb-13380 & Pit 1612 & Sheep burial & -20.7 & Baden III & $3550 \pm 50$ & $\begin{array}{l}1956-1776(68.2 \%) \\
2024-1750(95.4 \%) \\
\end{array}$ \\
\hline KI-16688 & Pit 2104 & $\begin{array}{c}\text { Animal } \\
\text { bone }\end{array}$ & -20.1 & $\begin{array}{l}\text { Late Somogyvár- } \\
\text { Vinkovci/proto- } \\
\text { Kisapostag }\end{array}$ & $3460 \pm 60$ & $\begin{array}{l}1879-1693(68.2 \%) \\
1928-1626(95.4 \%)\end{array}$ \\
\hline
\end{tabular}


raises the possibility, no matter how slight, that the two cultures had succeeded one another. This issue can only be resolved in the light of new dates from secure contexts.

\section{Assessment}

In view of the fact that the clay funnel from Balatonöszöd does not have a single truly solid formal analogy, we have turned to a handful of less similar artefacts dating from the $3^{\text {rd }}-2^{\text {nd }}$ millennium $B C$ which could provide clues in determining the function of this enigmatic find.

The lavishly ornamented funnel from Gruda Boljevica, used for the manipulation of liquids during a funeral ceremony, is analogous insofar as it supports the possibility that the piece from Balatonöszöd had similarly been used for pouring liquids. ${ }^{6}$ This function is suggested by the artefact's form, but does not bring us closer to the type of liquid itself.

The two other similar types quoted above differ significantly from the Balatonöszöd funnel regarding their form because they have a plain exterior and interior with neither of them having a spout. Regarding their possible function, the pieces from the Catacomb graves of the southern Russian steppe were interpreted as artefacts used during dairying, while a metallurgical use was proposed for the one from Lower Austria.

It would appear that the Balatonőszöd funnel had been subjected to a strong secondary heat effect. The funnel from Unter-Mamau was interpreted as part of a tuyère attached to leather bellows and was thus not subjected to a temperature of over $1,000^{\circ} \mathrm{C}$ needed for smelting, although it was exposed to a much hotter environment than other domestic articles fashioned from clay owing to its use for channelling

${ }^{6}$ No analyses were performed to determine the type of liquid which was poured or the substance which was burnt (hallucinogenic plant/cannabis, incense, myrrh, or some other substance). The decorated footed bowls of the Early Bronze Age are often interpreted as incense burners, principally based on comparable finds from the Russian steppe. Scythian analogies suggest that they were used for burning cannabis (for a comprehensive discussion, cp. Kaiser 2003, 282-288). However, it must be noted that Russian scholars only regard one particular variant of footed bowls as incense burners, known as kurilnica (Räucherschale/censer): the small, decorated or plain deep bowls set on a fenestrated, cross shaped foot. A dividing wall divides the bowl's interior into a smaller and larger part, making the bowls seem a combination of the footed chalices and the bipartite bowls of the Baden culture. Footed bowls of this type occur in the northern Azovian and northern Donets distribution of the Catacomb culture and, more rarely, in the northern Donets-Lower Don distribution of the late Manych type, for example at Mozdoksteppe, Komarovo K7/10, K2/11, 19, Černojarskaja K1/9, Troickoe K1/5 and Kievskoe K1/7, 10, K2/12 (Nagler 1996, Tafle 63.13, Tafle 72, Tafle 87, Tafle 89, Tafle 96, Tafle 97.7, Tafle 98.1, Tafle 109.1, Tafle 111.1, Tafle 113). The footed bowl from the Montenegro burial, however, represents a different type. It should also be noted that the purpose of the fumigation ritual is not always the burning of a substance with a pleasing fragrance as an act of reverence to the Sacred/ Numinous or to fall into a trance. In Islam, for example, the circumcision ceremony of three to seven year old boys involved the boy's nurse carrying a brass incense burner on her head, in which a mixture of gum and salt was burnt: the purpose of this rather pungent smell was to ward off the evil eye. This apotropaic rite is extremely ancient and was practised by desert peoples well before the appearance of Islam (Germanus 1984, 476). hot air. A possible function of this type conforms more to the secondary heat effect of $600-800^{\circ} \mathrm{C}$ which the Balatonőszöd funnel had been exposed to. We also are aware that a lower temperature of $700-800^{\circ} \mathrm{C}$ was sufficient for smelting fahlerz ores (cp. Durman 1983). This possibility can only be confirmed or rejected by additional analyses in the future.

An interpretation of the funnel's function along similar lines is contradicted by the artefact's exterior and interior surface treatment of heavy scoring and the whitish residue surviving in the scoring in its interior. A similar scoring and a calcareous fill has been noted in the interior of Early Bronze Age crucibles and, more rarely, on the exterior of tuyères, as for example on the piece from Zók-Várhegy (Vučedol culture). The flat, semi-spherical crucibles shown in Figures 39-40 and 42 of István Ecsedy's study were all spouted (Ecsedy 1982, 72, 75, 79-82). A tuyère decorated with longitudinal grooving is known from Vučedol (Koledin 2004, Figure 2b) and the bivalve moulds for daggers found at Sarvaš also bear incisions on their exterior (Balen 2005, 51, Figure 39, Pl. 59-60, cat. nos 226-227). The spout on the rim belies a function as a tuyère because it would have been most impractical if attached to leather bellows and could have only fulfilled its intended function with great difficulty.

The function of a milk strainer seems more plausible in view of the spout on the funnel. In addition, the vitrification on the rim can perhaps be associated with boiling milk or with the practice of placing the funnel on the edge of the hearth's platter. The only problem with this is that milk or any other dairy product for that matter simply does not exist at $600^{\circ} \mathrm{C}$ : even the most modern pasteurisation and preservation procedures heat milk and dairy products up to a temperature of approximately $100^{\circ} \mathrm{C}$ (in the ESL technology, milk is heated at $134^{\circ} \mathrm{C}$ for 0.1 seconds), not to speak of the fact that this technology was unknown and unnecessary in prehistory. A temperature of $600-800^{\circ} \mathrm{C}$ could only be achieved by a constant, intensive fire lasting several hours using some sort of constructed heating installation (pit firing, a furnace or the burning of a house); a temperature at this range could not be achieved in a hearth or oven used for cooking and would not have been necessary because most foods can be cooked at $180-220^{\circ} \mathrm{C} .^{7}$

${ }^{7}$ Milk may have been used as an ingredient in cooking and baking, and it is therefore instructive to review the food types made using milk in prehistory. The currently known earliest cookbook was written by the Roman Marcus Gavius Apicius who lived in the 1 st century $\mathrm{AD}$, during the reign of Tiberius. Although a number of recipes were added later, in the $2^{\text {nd }}$ and $4^{\text {th }}$ centuries, about three-fifths of the recipes were in all probability written by Apicius and the origins of the simpler dishes can most likely be traced to earlier periods (ApICIUs). The collection of recipes contains a description of Greek/Hellenistic and eastern cuisine and, obviously, the ingredients used for their dishes. Milk was used for several purposes, for example, for making salted meats sweet by boiling them in milk and then in water, and in a wide variety of dishes such as milk soufflé with sea urchins, creamed chicken with milky paste, a dish of milk-fed snails, lamb with milk toast and kid roasted or cooked with milk. The latter probably resembled the Patriarch Isaac's favourite dish, the savoury meat he asked Esau to prepare for him before giving his blessing (which was stolen by Jacob through his 
It would appear that during the Early Bronze Age, the funnel form was consistently used in the period's two major technological/economic innovations, namely dairying and metal/bronze production. It is possible that the two, seemingly unrelated functions, were coupled as part of a funerary ceremony as two successive elements of the burial rite (perhaps as a symbolic element of fire and of its opposite or complementary substance, i.e. liquid/water). However, we did not discover any ritual features or finds at the Early Bronze Age settlement at Balatonőszöd, or any artefacts that could be associated with metalworking and dairying or dairy products.

We are of the opinion that the Balatonöszöd funnel was in all probability used in metalworking, in a phase during which it came into contact with hot metal and/or fire indirectly, for a brief time. In view of its form, it may have been used during the production of artefacts such as daggers, axes and pickaxes cast in bivalve moulds calling for the more sophisticated casting technology appearing during the Early Bronze Age (for the metallurgy of the Late Copper Age and the Early Bronze Age in Transdanubia, see Ecsedy 1982; 1990; 1994; for the metallurgy of the Early Bronze Age 2-3, see Torma 1978; Kiss 2002; 2009. For an overview of the technology of Middle Bronze Age metalworking, see, e.g., Horváth 2004). After joining and fixing the two halves of the mould, the molten metal was poured into the mould from a crucible by placing the stem of the funnel to the opening of the mould. The molten metal passed through the funnel, but did not remain in it for a long time. The use of the funnel ensured the even distribution of the molten bronze in the mould, as well as the more efficient and economical utilisation of the metal. In order to test this hypothesis, we would have to examine the openings of the known bivalve moulds to establish whether there was a variation in their size and whether there was some sort of standard, particularly in view of the fact that the dimensions of most moulds and the diameter of the shaft were adjusted to the size of a human palm, and thus size variations would be no more than a few millimetres. The published data in studies on Early Bronze Age metalworking make it virtually impossible to assemble reliable data on this casting phase and, moreover, the currently known moulds come from various periods and sites of the Early Bronze Age, and it is therefore not possible to test this hypothesis. (See, for example, the Early Bronze Age moulds for axes: Bátora 2002; Kaiser 2005; Kővári, Patay 2005 and daggers: Balen 2005, Pls 59-60). ${ }^{8}$

cunning; Gen. 27). This typical nomadic dish of the desert peoples was later prohibited by Jewish dietary laws: the prohibition appears twice in the Mosaic laws formulated after the Exodus: "Thou shalt not seethe a kid in his mother's milk" (Ex. 23,19; 34,26).

${ }^{8}$ Most studies only specify the dimensions of the moulds and the cast items but do not mention the size of the opening through which the molten metal was poured into the mould. The illustrations to the studies either lack an exact scale or are not drawn to scale making it impossible to make even a reasonable estimate of the size. The opening on the bivalve dagger mould from Sarvaš is roughly $2.5-3 \mathrm{~cm}$ large, corresponding to the opening at the base of the stem of the Balatonöszöd funnel. Due to the lack of experiments,
The current evidence neither proves, nor disproves the possible functions discussed above. Due to a lack of further analogies and educated guesses on possible other uses, as well as the absence of reference finds, the one-time function of the clay funnel from Balatonőszöd remains an unresolved enigma.

\section{Acknowledgements}

The study was prepared as part of a research project funded by Grant OTKA F-67577 and Grant PD-73490.

We are greatly indebted to Elisabeth Ruttkay ( $\dagger$ ) for her help in locating the funnel shaped artefact from UnterMamau in the museum's collection and to Anton Kern, director of the prehistoric collection of the Naturhistorisches Museum, for his kind permission to publish the find.

The X-ray powder diffraction analysis was carried out in the Chemical Research Centre of the Hungarian Academy of Sciences. The assessment of the results was performed by Mária Tóth. The petrographic analysis was made by Katalin Gherdán.

The TL/OSL measurements were performed at Szeged University under the supervision of György Sipos, who assessed the results.

\section{References}

APICIUS: Cooking and Dining in Imperial Rome, by Apicius. http://www. gutenberg.org/files/29728/29728-h/29728-h.htm

BÁTORA, J. 2002: Contribution to the problem of "Craftsmen" graves at the end of Aeneolithic and in the Early Bronze Age in Central, Western and Eastern Europe. Slovenská Archeológia 50/2, 179-228.

BAKOVIĆ, M., GOVEDARICA, B. 2009: Nalazi iz kneževskog tumula Gruda Boljevića u Podgorici, Crna Gora - Findings from the Princely Tomb of Gruda Boljevića in Podgorica, Montenegro. Godišnjak Centra za Balkanološka Ispitivanja Akademije Nauka i Umjetnosti Bosne $i$ Hercegovine 36, 5-23.

BALEN, J. 2005: Sarvaš - Neolitičko i eneolitičko naselje - Sarvaš Neolithic and Eneolithic settlement. Katalozi i monografije Arheološkog muzeja u Zagrebu - Catalogues and monographs of the Archaeological Museum in Zagreb 2, Zagreb.

DURMAN, A. 1983: Metalurgija vučedolskog kulturnog kompleksa Metallurgy of the Vučedol culture complex. Opuscula Archaeologica 8, $1-74$.

ECSEDY, I. 1982: Ásatások Zók-Várhegyen (1977-1982). Előzetes jelentés - Excavations at Zók-Várhegy (1977-1982) Preliminary Report. Janus Pannonius Múzeum Évkönyve 27, 59-107.

ECSEDY, I. 1990: On the Early Development of Prehistoric Metallurgy in Southern Transdanubia. Godišnjak Centra za Balkanološka Ispitivanja Akademije Nauka i Umjetnosti Bosne I Hercegovine 26, 209-231.

ECSEDY, I. 1994: Copper Age Traditions and Bronze Age Innovations. In: Kovács, T. (Ed.): Treasures of the Hungarian Bronze Age. Catalogue to the Temporary Exhibition of the Hungarian National Museum September 20-December 31, 1994. Budapest, 37-45.

it is unclear whether it was more practical to simply hold the funnel to the mould's opening or whether the funnel should fit through it the mould's interior (meaning that the base of the funnel's stem must be smaller than the opening). The form of the smooth, wide base of the stem of the Balatonöszöd funnel would suggest the former alternative. 
GERMANUS, Gy. 1984: Allah Akbar! Szépirodalmi könyvkiadó, Budapest. GHERDÁN, K. 2009: 7000 év kerámiái. Vörs, Máriaasszony-sziget öskori kerámialeleteinek archeometriai összehasonlító vizsgálata területi kitekintéssel - Pottery sequence of 7000 years: archaeometrical study of pottery finds from Vörs, Máriaasszony-sziget. Archeometriai Mühely 2009/4, 31-36.

GHERDÁN, K., HORVÁTH, T. 2009: Petrographic investigation on the finds of Balatonőszöd-Temetői-dülő Baden settlement. In: T. Biró, K., Szilágyi, V., Kreiter, A. (Eds): Vessels: Inside and Outside. Proceedings of the Conference EMAC'07, $9^{\text {th }}$ European Meeting on Ancient Ceramics, 24-27 October 2007, Hungarian National Museum, Budapest, Hungary. Hungarian National Museum, Budapest, 265-276.

GHERDÁN, K., HORVÁTH, T., TÓTH, M. 2012: Lehetőségek a kerámiakőzettani kutatásokban. Esettanulmány egy több-periódusú lelőhelyen (Balatonőszöd-Temetői-dülő, M7/S-10 lelőhely) - Potentials in ceramic petrography research. A case study at a multi-period site (BalatonőszödTemetői-dűlő, M7 / S-10). In: Kreiter, A., Pető, Á., Tugya, B. (Eds): Környezet-Ember-Kultúra. A természettudományok és a régészet párbeszéde - Environment-Human-Culture. Dialogue between applied sciences and archaeology. Budapest, 291-305.

GHERDÁN, K., TÓTH, M., HERBICH, K., HAJNALOVÁ, M., HLOŽEK, M., PROKEŠ, L., MIHÁLY J., HORVÁTH, T. 2010: Természettudományos megfigyelések a középső és késő rézkori kultúrák fazekasáruin Balatonőszöd-Temetői-dűlő lelőhelyen - Analytical data on the Middle and Late Copper Age pottery production at BalatonőszödTemetői-dülö. Archeometriai Mühely 2010/1, 83-104.

GEORGHIU, D. 2003: Building a Ceramic Macroobject: The 2003 Vadastra Project experiments. The Old Potter Almanach 2003, 1-5.

GOVEDARICA, B. 2010: Grab- und Opferfunde aus dem Hügel Gruda Boljevića in Montenegro (erste Hälfte des 3. Jahrtausend v. Chr.). In: Šuteková, J., Pavúk, P., Kalábková, P., Kovár, B. (Eds): Pantha Rhei. Studies on the Chronology and Cultural Development of South-Eastern and Central Europe in Earlier Prehistory. Presented to Juraj Pavúk on the Occasion of his 75th Birthday. Bratislava, 179-188.

HÄUSLER, A. 1974: Die Gräber der älteren Ockergrabkultur zwischen Ural und Dnepr. Martin-Luther-Universität Halle-Wittenberg (HalleSaale), Berlin.

HORVÁTH, T. 2004: Néhány megjegyzés a vatyai kultúra fémművességéhez - Technológiai megfigyelések a kultúra kőeszközein - Die Metallkunst der Vatya-Kultur - Technologische Beobachtungen an ihren Steingeräten. Communicationes Archaeologicae Hungariae 2004, 11-64.

HORVÁTH, T. 2009: The intercultural connections of the Baden culture. In: Ilon, G. (Ed.): MSMO 2 6. Öskoros Kutatók VI. Összejövetelének konferenciakötete. Köszeg, 2009. március 19-21. Nyersanyagok és kereskedelem. Szombathely-Budapest, 101-149.

HORVÁTH, T. 2010: Megfigyelések a középső és késő rézkori kultúrák fazekasáruin Balatonőszöd-Temetői-dűlő lelőhelyen. Készítéstechnikai vizsgálatok - Archaeological contribution to the study of the Middle and Late Copper Age pottery. Archeometriai Mühely 2010/1, 51-82.

HORVÁTH, T. 2011a: A késő rézkor időszaka más szemszögből: tipokronológiai megfigyelések a Balatonőszöd-Temetői dülői késő rézkori Boleráz/Baden település leletanyagán. GESTA 10, 3-135, http://www. tortenelemszak.uni-miskolc.hu/gesta/gesta 2011.

HORVÁTH, T. 2011b: A Boleráz, Baden és Kostolac kultúrák kronológiai és térbeli helyzete, és interkulturális kapcsolatai. Specimina Electronica Antiquitatis 12, 1-105. http://www.okor.tti.btk.pte.hu/menu/18
HORVÁTH, T., SIPOS, G., MAY, Z., TÓTH, M. 2010: The date of the Late Copper Age ritual mask from Balatonőszöd/Temetői dülö. Antaeus 31-32, 499-513.

KAISER, E. 2003: Studien zur Katakombengrabkultur zwischen Dnepr und Prut. Archäologie in Eurasien 14, Mainz.

KAISER, E. 2005: Frühbronzezeitliche Gräber von Metallhandwerkern mit Gußformen für Schaftlochäxte. In: Horejs, B., Jung, R., Kaiser, E., Teržan, B. (Eds.): Interpretationsraum Bronzezeit. B. Hänsel von seinen Schülern gewidmet. Universitätsforschungen zur prähistorischen Archäologie 121, Bonn, 265-293.

KALICZ, N. 1976: Ein neues kupferzeitliches Wagenmodell aus der Umgebung von Budapest. In: Mitscha-Märheim, H., Friesinger, H., Kerchler, H. (Eds.): Festschrift für Richard Pittioni zum siebzigsten Geburtstag. Archaeologia Austriaca Beiheft 13, Wien, 188-202.

KISS, V. 2002: A mészbetétes kerámia kultúrája telepei és temetői a Közép- és Dél-Dunántúlon. PhD disszertáció, kézirat. ELTE BTK Régészettudományi Intézet. Budapest.

KISS, V. 2009: A fém nyersanyag-felhasználás kérdései a Dunántúl kora és középső bronzkorában - Questions of the use of metal raw material in the Early and Middle Bronze Age of Transdanubia. In: Ilon, G. (ed.): $M \Omega M O \Sigma$ 6. Öskoros Kutatók VI. Összejövetelének konferenciakötete. Köszeg, 2009. március 19-21. Nyersanyagok és kereskedelem. Szombathely-Budapest, 197-212.

KOLEDIN, J. 2004: Tipologija i razvoj duvaljki u praistorijskoj metalurgiji - The development of the typology and the pre-historic metallurgy - the tombs of pre-historic metallurgists. Rad Vojvodanskih Muzeja 46, 79100.

KÖVÁRI, K., PATAY, R. 2005: A settlement of the Makó culture at Üllő. New evidence for Early Bronze Age metalworking. Communicationes Archaeologicae Hungariae 2005, 83-137.

KREITER, A. 2006: Kerámia technológiai vizsgálatok a Halomsíros kultúra Esztergályhorváti-alsóbárándpusztai településéről: hagyomány és identitás - Technological examination of Tumulus culture pottery from Esztergályhorváti-Alsóbárándpuszta: tradition and identity. Zalai Múzeum 15, 149-170.

LICHTER, C. 2010 (Ed.): Jungsteinzeit im Umbruch. Die "Michelsberger Kultur” und Mitteleuropa vor 6000 Jahren. Badisches Landesmuseum, Karlsruhe.

MELLER, H. 2004 (Ed.): Der geschmiedete Himmel. Die Welt im Herzen Europas vor 3600 Jahren. Theiss Verlag, Stuttgart.

NAGLER, A. 1996: Kurgane der Mozdok-Steppe in Nordkaukasien. Archäologie in Eurasien 3, Espelkamp.

SHISHLINA, N. I. 2001: Early Herders of the Eurasian Steppe. Expedition 43/1, 21-28.

SHISHLINA, N. I., CUCKIN, E. V., FIRSOV, K. B. 1999: Archeologiczeskoie isledovanie mogilnika Mandjikini v iki-burulskom raionie Respubliki Kalmykija. In: Mogilnik Manjikiny 1. Pamiatnik epochy bronzy-ranego zieleznogo veka Kalmykii (Opyt kompleksogo issledovania). Gosudarstvennyj istoriczeskij muzej Kalmykin Instytut Cocialno-ekonomiczeskich i pravovych issledovanij. Moszkva, Eliszta, 5-32.

SCHMIDT, R. R. 1945: Die Burg Vučedol. Ausgabe des Kroatischen Archäologischen Staatsmuseums in Zagreb, Zagreb.

TORMA, I. 1978: A balatonakali bronzkori sír - Das bronzezeitliche Grab in Balatonakali. Veszprém Megyei Múzeumok Közleményei 13, 15-24.

VULIĆ, N., GRBIĆ, M. 1938: Corpus Vasorum Antiquorum Yougoslavie 3. Belgrade. 